\title{
Prevalence of overweight and obesity among police officers in Riyadh City and risk factors for cardiovascular disease
}

\author{
Abdullah S. Alghamdi ${ }^{1}$, Mohammed A. Yahya ${ }^{2}$, Ghedeir M. Alshammari ${ }^{2 *}$ and Magdi A. Osman²
}

\begin{abstract}
Background: Despite the prevalence of overweight and obesity and increases in associated diseases such as diabetes and heart disease in the Saudi population, no studies have addressed the spread of obesity among Saudi police officers. Therefore, the present study aimed to assess the prevalence of overweight and obesity and associations with biochemical parameters among the police in Riyadh.
\end{abstract}

Method: The study involved a cross-sectional survey of 160 police officers in Riyadh, Saudi Arabia. Anthropometric measurements, blood pressure, lipid profiles and fasting blood sugar levels were measured for all individuals.

Results: According to the results, the average body mass index (BMI) was $27.5 \pm 5.1$, indicating an increase in overweight in this population and $66.9 \%$ were overweight or obese. Moreover, the mean systolic and diastolic blood pressure values were 119.5 and $79.4 \mathrm{mmHg}$, respectively, within normal limits. The mean total cholesterol (TC), high-density lipoprotein-cholesterol (HDL-C), low-density lipoprotein-cholesterol (LDL-C), and triglyceride (TG) levels were 187.5, 43.9, 119.5 and $124.5 \mathrm{mg} / 100 \mathrm{ml}$, respectively.

Discussion: These BMI and biochemical findings suggest a high proportion of overweight and obese individuals in the sample population, as well as an increase in the proportion of individuals with high levels of biochemical indicators who are therefore susceptible to heart disease and diabetes.

Conclusion: The study recommends using preventive programs to combat obesity and overweight and related diseases and conducting further studies using measures other than BMI.

\section{Background}

Generally, police work is recognized as a dangerous occupation, and the health of police officers must be considered [1]. In all countries, police officers play important roles by ensuring security and stability. These individuals perform specialized work involving exposure to violence, which can affect their health directly or indirectly. Currently employed police personnel have also been reported to have a high prevalence of obesity and related diseases such as hypertension, hyperlipidemia, cigarette smoking and sedentary lifestyle [2].

Police officers generally face increased risks of hyperlipidemia and metabolic syndrome, conditions that

\footnotetext{
* Correspondence: aghedeir@ksu.edu.sa

${ }^{2}$ Metabolic Disorders Lab, Food Science and Nutrition Department, College of Food and Agricultural Sciences, King Saud University, P.O. Box 2460, Riyadh 11451, Saudi Arabia

Full list of author information is available at the end of the article
}

contribute to a higher prevalence of cardiovascular disease [3-5]. Epidemiological reports have demonstrated a higher prevalence of obesity among police officers, compared to non-police workers. Therefore, it is important to investigate the associations between body weight and biochemical parameters. Accordingly, treatment and preventive strategies should be implemented to improve the abilities of these officers during work periods [6, 7]. Recently, some.

Obesity is caused by an imbalance between energy intake and energy expenditure [8-10]. One of the most recent global estimates found that roughly 500 million adults are obese. Obesity is a complex condition with serious physical and psychological impacts on overall health. It has been defined by the World Health Organization (WHO) as abnormal or excessive fat accumulation that may impair health. In contrast, overweight is defined as a body mass index (BMI) of $\geq 25 \mathrm{~kg} / \mathrm{m}^{2}$. 
The WHO uses BMI, which is calculated by dividing weight (in $\mathrm{kg}$ ) by the squared height (in meters), to classify obesity [11]. The many benefits of economic growth are countered by the negative impacts on health, including a poor diet, sedentary lifestyle, and obesity [12, 13]. In the Eastern Mediterranean Region, obesity may cause non-communicable diseases such as diabetes mellitus, cerebral hypertension, cardiovascular disease, various cancers, osteoarthritis, and breathing disorders [14]. Obesity has become a major concern in Saudi Arabia because of these related diseases. Diet and nutrition, physical activity, education, and cultural environment have all been linked to the prevalence of obesity [15]. In an Indian study, most police officers $(68 \%)$ ranged in age from 25 to 39 years. The prevalence of hypertension in this population was $56.86 \%$, and $43.13 \%$ of officers were newly diagnosed. A waist circumference $>90 \mathrm{~cm}$ was associated with a higher prevalence of hypertension among police personnel [16].

The prevalence of obesity in Saudi Arabia is approximately $28 \%$ in males and $44 \%$ in females [17]. AlQahtani et al. [18] conducted a study of the obesity prevalence in Saudi adult soldiers, not including police officers. The study involved a cross-sectional survey of 2250 Saudi male soldiers aged 20-60 years who resided in northern Saudi Arabia. Anthropometric measurements, blood pressure, a brief medical history, serum lipid profile, and fasting plasma sugar measurements were requested for all subjects. The authorsobserved prevalence rates of $82 \%, 32 \%$, and $29 \%$ for overweight and obesity, elevated triglyceride levels, and high blood pressure.

To our knowledge, no previous research has addressed the prevalence of overweight and obesity among Saudi police officers and the relationships between lipid profiles and weight in this population. Therefore, the present study aimed to examine the associations between weight and individual biochemistry measurements in Saudi police officers.

\section{Methods}

In this cross-sectional survey, 160 male police officers working in Riyadh city voluntarily agreed to participate in this study. All participants received questionnaires including questions about demographic data such as age, social status, number of family members, monthly income, educational level, military rank, personal history and health, physical activity, smoking status, and types of foods and beverages consumed. These questionnaires were distributed to police stations in Riyadh city, and officers' body weights were measured by the researchers, who then calculated BMI values to yield units of $\mathrm{kg} / \mathrm{m}^{2}$. Study participants were divided into four categories according to BMI: $<18.5$ (underweight), 18.5-24.9 (normal), 25-29.9 (overweight) and $\geq 30$ (obese) [19]. Each participant was then supplied with a requisition for laboratory investigation after an overnight (12-h) fast. The requested laboratory tests included fasting plasma glucose (FPG), serum total cholesterol (TC), triglycerides (TG), low-density lipoprotein-cholesterol (LDL-C), and high-density lipoprotein-cholesterol (HDL-C). Blood pressure was measured after the participant rested in the waiting room for 10-15 min. The measurements were conducted using a standard mercury sphygmomanometer while the subject sat in an office chair with an arm resting on the table. The point of appearance of the first Korotkoff sound was defined as the systolic blood pressure (SBP), whereas the point of disappearance of the last Korotkoff sound indicated the diastolic blood pressure (DBP); measurements were made to the nearest millimeter of mercury $(\mathrm{mm} \mathrm{Hg})$.

\section{Statistical analysis}

Data are expressed as means \pm standard errors (SEs). Differences between groups were analyzed using a one-way analysis of variance, followed by Duncan's Multiple Range (DMR) test. SPSS 21.0 software (SPSS Inc., Chicago, IL, USA) was used for the analyses. Differences were considered statistically significant at $P$ values $<0.05$.

\section{Results and discussion}

Most previous studies that have assessed the prevalence of obesity in the Saudi population have reported varied results, with prevalence rates ranging from 16 to $46 \%$ for clinical obesity and from 29 to $35 \%$ for overweight. Only one study, conducted by Al-Qahtani et al. [18], has evaluated active service personnel in the armed forces of Saudi Arabia. Our results, shown in Table 1, demonstrate that the police officers in this study ranged in age from 20 to 56 years (mean of age $=34.4 \pm 8.3$ years). The average weight, height, BMI, systolic blood pressure, and diastolic blood pressure were $79 \pm 15.2 \mathrm{~kg}, 169.6 \pm 6.3 \mathrm{~cm}, 27.5 \pm 5.1 \mathrm{~kg} / \mathrm{m}^{2}$, $119.5 \pm 13.9 \mathrm{mmHg}$, and $79.4 \pm 11.9 \mathrm{mmHg}$, respectively.

The distribution of participating police officers into four BMI groups was as follows: underweight, 1.3\%; normal, 31.9\%; overweight, $42.5 \%$; and obese, $24.4 \%$ (Table 2). Subjects with BMI values within the underweight and normal

Table 1 Anthropometric and laboratory values among obese and non-obese participants

\begin{tabular}{ll}
\hline Characteristics & Mean \pm standard error \\
\hline Age (years) & $34.4 \pm 8.3$ \\
Weight $(\mathrm{kg})$ & $79 \pm 15.2$ \\
Height $(\mathrm{cm})$ & $169.6 \pm 6.3$ \\
Body mass index $(\mathrm{BMI})\left(\mathrm{kg} / \mathrm{m}^{2}\right)$ & $27.5 \pm 5.1$ \\
Systolic blood pressure $(\mathrm{mm} \mathrm{Hg})$ & $119.5 \pm 13.9$ \\
Diastolic blood pressure $(\mathrm{mm} \mathrm{Hg})$ & $79.4 \pm 11.9$ \\
\hline
\end{tabular}


Table 2 Distribution of participants according to body mass index (BMI) classification

\begin{tabular}{ll}
\hline BMl category & Percentage $(\%)$ \\
\hline Underweight $\left.)<18.5 \mathrm{~kg} / \mathrm{m}^{2}\right)$ & $1.3 \%$ \\
Ideal weight $\left(18.5-25.0 \mathrm{~kg} / \mathrm{m}^{2}\right)$ & $31.9 \%$ \\
Overweight $\left(25.1-29.9 \mathrm{~kg} / \mathrm{m}^{2}\right)$ & $42.5 \%$ \\
Obese $\left(\geq 30.0 \mathrm{~kg} / \mathrm{m}^{2}\right)$ & $24.4 \%$ \\
Total & $100 \%$ \\
\hline
\end{tabular}

ranges accounted for only $33.2 \%$ of the study population. In other words, more than $66.9 \%$ of the study subjects were either overweight or obese. These results are similar to those from the study by Al-Qahtani et al. [18] who observed prevalence rates of $43.9 \%$ and $81.4 \%$ for overweight and obesity among Saudi adult soldiers in northern Saudi Arabia. The prevalence rates of overweight and obesity among police officers in this study may be attributable to poor levels of health and nutritional awareness, increased intake of fatty foods and sugars, and a low level of physical activity. A strong association between obesity and lack of physical activity has been observed among Saudi adolescents [20].

Table 3 shows that police officers involved in this study had an average blood sugar level of $94.9 \mathrm{mg} /$ $100 \mathrm{ml}$ and average TC, TG, HDL-C and LDL-C levels of $187.5 \mathrm{mg} / 100 \mathrm{ml}, 124.5 \mathrm{mg} / 100 \mathrm{ml}, 43.9 \mathrm{mg} / 100 \mathrm{ml}$ and $119.5 \mathrm{mg} / \mathrm{ml}$, respectively.

The results in Table 4 demonstrate that $37 \%$ of participants in this study had a high TC level $(\geq 200 \mathrm{mg} /$ $100 \mathrm{ml}$ ). Moreover, $34 \%$ and $14 \%$ had a low level of HDL-C and high level of LDL-C, respectively ( $<40 \mathrm{mg}$ / $100 \mathrm{ml}$ and $>150 \mathrm{mg} / 100 \mathrm{ml}$, respectively). These results agree with those reported by Al-Nozha et al. [21], who noticed that Saudi males was $54.9 \%$ of Saudi men had elevated levels of cholesterol, and by Ogbeide et al. [22], who observed that $43.3 \%$ of males in Al-Kharj city had a cholesterol level > $200 \mathrm{mg} / 100 \mathrm{ml}$.

Our study results suggest a positive relationship between blood cholesterol levels and BMI among participants, as $48.6 \%, 37.8 \%$ and only $13.5 \%$ of those with high cholesterol were obese, overweight, and normal weight,

Table 3 Biochemical parameters of individuals participating in the study

\begin{tabular}{ll}
\hline Biochemical parameter & Value (mean \pm standard error) \\
\hline Blood sugar, $\mathrm{mg} / 100 \mathrm{ml}$ & $94.9 \pm 8.3$ \\
Total cholesterol, $\mathrm{mg} / 100 \mathrm{ml}$ & $187.5 \pm 32.9$ \\
$\begin{array}{l}\text { High-density lipoprotein cholesterol, } \\
\mathrm{mg} / 100 \mathrm{ml}\end{array}$ & $43.9 \pm 8.6$ \\
Low-density lipoprotein cholesterol, & $119.5 \pm 24.4$ \\
$\mathrm{mg} / 100 \mathrm{ml}$ & \\
Triglycerides, $\mathrm{mg} / 100 \mathrm{ml}$ & $124.5 \pm 50.9$ \\
\hline
\end{tabular}

Table 4 Percent values of some health indicators according to body mass index category

\begin{tabular}{lllll}
\hline Biochemical parameters & $\begin{array}{l}\text { \% Of the study } \\
\text { sample }\end{array}$ & $\begin{array}{l}\text { Ideal } \\
\text { weight }\end{array}$ & Overweight & Obese \\
\hline $\begin{array}{l}\text { Blood sugar } \\
>110 \mathrm{mg} / 100 \mathrm{ml}\end{array}$ & $12.0 \%$ & 16.7 & 25.0 & 58.3 \\
$\begin{array}{l}\text { Total cholesterol } \\
>200 \mathrm{mg} / 100 \mathrm{ml}\end{array}$ & $37.0 \%$ & 13.5 & 37.4 & 48.6 \\
$\begin{array}{l}\text { High-density lipoprotein } \\
\text { cholesterol }\end{array}$ & $34.0 \%$ & 50 & 23.5 & 26.5 \\
$<40 \mathrm{mg} / 100 \mathrm{ml}$ & & & & \\
$\begin{array}{l}\text { Low-density lipoprotein } \\
\text { cholesterol < } 150 \mathrm{mg} /\end{array}$ & $14.0 \%$ & 21.4 & 21.4 & 57.1 \\
$\begin{array}{l}100 \mathrm{ml} \\
\text { Triglycerides }\end{array}$ & & & & \\
$>150 \mathrm{mg} / 100 \mathrm{ml}$ & $20.0 \%$ & 25.0 & 20.0 & 55.0 \\
$\begin{array}{l}\text { Systolic blood pressure } \\
>130 \mathrm{mmHg}\end{array}$ & $12.0 \%$ & 00 & 33.3 & 66.6 \\
$\begin{array}{l}\text { Diastolic blood pressure } \\
>90 \mathrm{mmHg}\end{array}$ & $13.0 \%$ & 00 & 38.5 & 61.5 \\
\hline
\end{tabular}

respectively. In addition, $57.1 \%$ and $21.4 \%$ of participants with increased LDL-C levels were obese and normal weight, respectively. Among subjects with low HDL-C, $26.5 \%$ were obese and $-23.5 \%$ were overweight. According to Table 4, $20 \%$ of participants had a high TG ratio (based on the normal level of TG less than $150 \mathrm{mg} /$ $100 \mathrm{ml}$ ), a lower rate than that reported by Al-Nozha et al. [21], who observed a high TG rate of $47.6 \%$ among adult males in Saudi Arabia. In addition, a previous study found that TG values increased with increasing BMI; normal-weight individuals had an average TG level of $110 \mathrm{mg} / 100 \mathrm{ml}$, whereas overweight and obese individuals had levels of $132 \mathrm{mg} / 100 \mathrm{ml}$ and $142.3 \mathrm{mg} /$ $100 \mathrm{ml}$, respectively [23]. Generally, the high levels of TG and cholesterol observed among police officers in our study may be due to the increased prevalence of overweight and obesity. Many previous studies have indicated a close link between obesity and increased cholesterol levels, possibly as a result of low LDL receptor activity levels and genetic factors, in addition to an increase in the consumption of saturated fats [24]. Poor health behaviors, which usually include a high intake of red meat, fried foods, and prepared food from restaurants, low intake of fiber-rich foods, and physical inactivity, may be the cause of the high blood lipid levels observed in police officers in the present study. In addition to the preceding factors, the requirement for night-shift security maintenance and related stressors could lead to increases in TG and cholesterol levels. This was previously noted by Azhari [25] who, in a study of employees in Jeddah city, observed increases in blood lipid levels among those who worked during the night shift, compared with those who worked during the day shift. A high blood cholesterol level is a risk factor for 
coronary heart blockage and consequent angina [26]. Therefore, obese individuals in this study, who have cholesterol levels that exceed normal limits, are susceptible to angina along with other risk factors that lead to disease such as hypertension, stress and physical inactivity. We additionally note that the majority of these factors were distributed among obese individuals in our sample.

On the other hand, the results in Table 4 indicate that $12 \%$ of participants exhibited notably elevated blood sugar levels $(>110 \mathrm{mg} / 100 \mathrm{ml})$; this result was higher than the $5.7 \%$ reported by Karim et al. [27] for adult males in a Saudi Arabian population. Increased body weight leads to elevated blood sugar levels; the study found that among participants with high blood sugar levels, approximately $58.3 \%$ were obese and $25 \%$ were overweight. Blood sugar levels increased with increasing BMI, as the rates among normal-weight, overweight, and obese participants were $6.1 \%, 7.7 \%$, and $25 \%$, respectively (Table 4). These results agree with those obtained by AlQahtani et al. [28] and Timar et al. [29], who reported a high blood sugar prevalence of $2.9 \%$ among normalweight individuals compared to $4.8 \%$ and $5.8 \%$ among overweight and obese individuals, respectively. The increased blood sugar levels observed in obese police officers may be attributable to several causes, including an increased intake of sugars and sweets and low intake of fiber-rich foods; notably, our analysis determined that $40.6 \%$ of participants never consumed brown bread, and more than half did not eat vegetables (fresh or cooked) on a daily basis. Other factors may also be attributable, such as a decreased insulin sensitivity, which is often associated with obesity and is a direct cause of high blood sugar levels. Christopher et al. [26] noted that overweight and obesity led to poor insulin sensitivity and was associated with increased blood sugar levels, increased intake of carbohydrate-rich foods, and a lack of physical activity [30]. Previous studies show benefits to use specific food to reduce risk factors of obesity and its related disease. For instant, the nutraceuticals ingredients are beneficial to vascular health may represent useful compounds that are able to reduce the overall cardiovascular risk induced by dyslipidemia [31]. As a result, we suggest to involve a functional food in food planning for police officers and another workers.

\section{Conclusion}

This study observed a high prevalence of overweight and obesity among Saudi police officers in Riyadh city. A comprehensive study of the factors that lead to the prevalence of obesity among Saudi police officers is needed, and preventive and remedial plans should be developed to protect these officers from obesity and associated complications.

\section{Abbreviations}

BMI: Body mass index; DBP: Diastolic blood pressure; DMR: Duncan's Multiple Range; FPG: Fasting plasma glucose; HDL-C: High-density lipoproteincholesterol; LDL-C: Low-density lipoprotein-cholesterol; SBP: Systolic blood pressure; SE: Standard error; TC: Total cholesterol (TC),; TG: Triglycerides; WHO: World Health Organization

\section{Acknowledgements \\ The authors thank the Deanship of Scientific Research, College of Food and Agricultural Sciences, Research Center, King Saud University, for financial support of this study. \\ Funding \\ This research was supported by King Saud University, Deanship of Scientific Research, college of food and agricultural sciences research center. This work was conducted in department of food science and nutrition.}

\section{Availability of data and material}

Data sharing not applicable to this article as no datasets were generated or analysed during the current study.

\section{Authors' contributions}

MA and AS were responsible for the concept and design of the study. GM, AS, and MA carried out the development of the model, data analysis and interpretation of results. AS diparticipated in the surveys, cleaning and archiving the data. MA and GM conceived the scientific oversight. GM with MA participated in its design and coordination and helped to draft the manuscript. All authors read and approved the final manuscript.

\section{Competing interests}

No conflict of interests is associated with this work.

Consent for publication

Not applicable.

\section{Ethics approval and consent to participate}

The study was approved by the hospital ethical committee board. Written informed consent was obtained from all patients and control subjects included in this study.

\section{Disclaimers}

Authors state that views expressed in the submitted manuscript are their own work.

\section{Publisher's Note}

Springer Nature remains neutral with regard to jurisdictional claims in published maps and institutional affiliations.

\section{Author details}

${ }^{1}$ Ministry of Inter, P.O BOX 61008, Abaha, Saudi Arabia. ${ }^{2}$ Metabolic Disorders Lab, Food Science and Nutrition Department, College of Food and Agricultural Sciences, King Saud University, P.O. Box 2460, Riyadh 11451, Saudi Arabia.

Received: 30 December 2016 Accepted: 4 April 2017

Published online: 14 April 2017

\section{References}

1. Reichard AA, Jackson LL. Occupational injuries among emergency responders. Am J Ind Med. 2010;53:1-11.

2. Plat MJ, Frings-Dresen MH, Sluiter JK. A systematic review of job-specific workers' health surveillance activities for fire-fighting, ambulance, police and military personnel. Int Arch Occup Environ Health. 2011;84:839-57.

3. Houser AN, Jackson BA, Bartis JT, Peterson DJ. Emergency responder injuries and fatalities: An analysis of surveillance data. Santa Monica (CA): National Personal ProtectiveTechnology Laboratory; Mar. Report No.: TR-100- NIOSH. 2004. Available from: http://www.rand.org/content/dam/rand/pubs/ technical_reports/2005/RAND_TR100.pdf.

4. Pyorala M, Miettinen $\mathrm{H}$, Halonen $\mathrm{P}$, Laakso M, Pyorala K. Insulin resistance syndrome predicts the risk of coronary heart disease and stroke in healthy 
middle-aged men: the 22-year follow-up results of the Helsinki policemen study. Arterioscler Thromb Vasc Biol. 2000;20:538-44.

5. Birnbaum HG, Mattson ME, Kashima S, Williamson TE. Prevalence rates and costs of metabolic syndrome and associated risk factors using employees' integrated laboratory data and health care claims. J Occup Environ Med. 2011:53:27-33.

6. Hartley TA, Burchfiel CM, Fekedulegn D, Andrew ME, Violanti JM. Health disparities in police officers: comparisons to the U.S. general population. Int J Emerg Ment Health. 2011;13:211-20.

7. Tharkar S, Kumpatla S, Muthukumaran P, Viswanathan V. High prevalence of metabolic syndrome and cardiovascular risk among police personnel compared to general population in India. J Assoc Physicians India. 2008;56:845-9.

8. Hopkins BD, Concalves MD, Cantley LC. Obesity and cancer mechanisms: cancer metabolism. J Clin Oncol. 2016;34:4277-83.

9. Müller MJ, Geisler C. From the past to future: from energy expenditure to energy intake to energy expenditure. Eur J Clin Nutr. 2017;71:358-64.

10. Zou T, Chen D, Yang Q, Wang B, Zhu MJ, Nathanielsz PW, et al. Resveratrol supplementation to high fat diet-fed pregnant mice promotes brown and beige adipocyte development and prevents obesity in male offspring. J Physiol. 2016.

11. World Health Organization. Obesity and over-weight. [Updated 2016; Accessed Sept 2014].

12. Jayawardena R, Byrne NM, Soares MJ, Katulanda P, Hills AP. Prevalence, trends and associated socio-economic factors of obesity in South Asia. Obes Facts. 2013;6:405-14.

13. Khan SH, Talukder SH. Nutrition transition in Bangladesh: is the country ready for this double burden. Obese Rev. 2013;14 Suppl 2:126-33.

14. Poirier P, Eckel RH. Obesity and cardiovascular disease. Curr Atheroscler Rep. 2002;:4:448-53.

15. Musaiger AO. Overweight and obesity in the eastern Mediterranean region: can we control it? East Mediterr Health J. 2004;10:789-93.

16. Ganesh KS, Naresh AG, Bammigatti C. Prevalence and risk factors of hypertension among male police personnel in urban Puducherry, India. Kathmandu Univ Med J (KUMJ). 2014;12:242-6.

17. Al-Nohair S. Obesity in gulf countries. Review Article. Int J Health Sci. 2014;8: 79-83.

18. Al-Qahtani DA, Imtiaz ML, Shareef MM. Obesity and cardio-vascular risk factors in Saudi adult soldiers. Saudi Med J. 2005;26:1260-8.

19. World Health Organization. Obesity, prevention and managing global epidemic. Report of WHO consultation on obesity. Geneva 3-5: 1997; 1998

20. Al-Rukban MO. Obesity among Saudi male adolescents in Riyadh, Saudi Arabia. Saudi Med J. 2003;24(1):27-33.

21. Al-Nozha MM, Arafah MR, Al-Maatouq MA, Khalil MZ, Khan NB, Al-Marzouki K, et al. Hyperlipidemia in Saudi Arabia. Saudi Med J. 2008;29:282-7.

22. Ogbeide DO, Karim A, Al-Khalifa IM, Siddique S. Population-based study of serum lipid levels in Al-Kharj health center, Saudi Arabia. Saudi Med J. 2004; 25:1855-7.

23. El-Hazmi MA, Warsy AS. Relationship between obesity, overweight and plasma lipids in Saudis. Saudi Med J. 1999;20:521-5.

24. Grundy SM, Barnett J. Metabolic and health complications of obesity. Dis Mon. 1990;36:641-731.

25. Azhari SA. Some of the physiological changes in the human blood caused by stress and anxiety, Master thesis. Jeddah, Saudi Arabia: Faculty of Science, King Abdulaziz University; 2005.

26. Christopher H, Edwin R, Nicholas A, Nicki R. Vitamins and minerals. In: Davidson's principles and practice of medicine. 19th ed. Edinburgh, London: Churchill Livingstone; 2002.

27. Karim A, Ogbeide DO, Siddiqui S, AI-Khalifa IM. Prevalence of diabetes mellitus in Saudi community. Saudi Med J. 2000;21:438-42.

28. Al-Qahtani DA, Imtiaz ML. Prevalence of metabolic syndrome in Saudi adult soldiers. Saudi Med J. 2005;26:1360-6.

29. Timar R, Rosu M, Pacuraru S, Crisan V. High blood pressure and metabolic disorders prevalence in obese individuals. Int J Obes. 2000;24 suppl 1:S1-53. (abstract)

30. Molly, G, Mahan K, Escott-Stump S. Weight management. In Mahan K. Krause's Food and Nutrition Therapy. 12th edition. Saunders Elsevier, INC; 2008.

31. Scicchitano P, Camelib M, Maielloc M, Modestid PA, Muiesane ML, Novof S, Palmieroc P, Sabag PS, Pedrinellih R, Cicconea MM. Nutraceuticals and dyslipidaemia: beyond the common therapeutics. J Funct Foods. 2014;6:11-32.

\section{Submit your next manuscript to BioMed Central and we will help you at every step:}

- We accept pre-submission inquiries

- Our selector tool helps you to find the most relevant journal

- We provide round the clock customer support

- Convenient online submission

- Thorough peer review

- Inclusion in PubMed and all major indexing services

- Maximum visibility for your research

Submit your manuscript at www.biomedcentral.com/submit 